УДК $811.163 .1+271.2-4$

DOI: $10.17223 / 19986645 / 43 / 2$

\title{
Л.В. Долгушина
}

\section{ЛАКУНЫ В ДРЕВНЕЙШЕМ СЛАВЯНСКОМ ПЕРЕВОДЕ ГОМИЛИЙ св. ГРИГОРИЯ БОГОСЛОВА}

\begin{abstract}
В статье сделан вывод, что отличия объема и состава славянского сборника «ХІІІ Слов Григория Богослова» от состава греческих коллекичии могут объясняться теми задачами, которые ставили перед собой создатели сборника, предназначая его для недавно принявших христианство славян и используя его для миссионерских иелей. Внимательное рассмотрение всех лакун славянского текста может пролить свет на некоторые до сих пор не решенные вопросы формирования сборника.

Ключевые слова: сборник, лакуны, Григорий Богослов, перевод, славянская письменность, греческий язык.
\end{abstract}

Среди произведений начального этапа существования славянской письменности значительную часть составляют переводные произведения, в первую очередь - с греческого языка. Одним из таких переводов является славянский сборник «XIII Слов Григория Богослова», дошедший до нас в рукописи XI в.

Этот сборник содержит древнейший перевод гомилий св. Григория Богослова на славянский язык. Уникальность этого сборника не только в его древности (другие дошедшие до нас рукописи с произведениями Григория Богослова относятся самое раннее к XIV в.), но также и в его составе. В рукописи XI в. находятся как так называемые «литургические» гомилии (т.е. те, которые по церковному уставу читаются на определенных богослужениях), так и гомилии, не используемые на церковных службах. Такой состав гомилий, как в сборнике «"ХIII Слов Григория Богослова"», не встречается ни в греческой традиции, ни в более поздней славянской. (В славянской традиции получил распространение сборник «XVI Слов Григория Богослова», который содержит литургические гомилии и представлен рукописями XIV в. и более поздними.)

У исследователей сборника «ХІІІ Слов Григория Богослова» до сих пор нет единодушия в определении места создания перевода, вызывает также вопросы его однородность (возможно, входящие в сборник гомилии были переведены в разное время и в разных переводческих школах).

Опубликованное в 1871 г. А.С. Будиловичем «Исследование языка древнеславянского перевода «ХІІІ Слов Григория Богослова»» является самым значительным по объему и широте привлекаемого материала научным трудом, посвященным этой рукописи. А.С. Будилович считал, что переводчиком всех «Слов» был один человек, но отмечал «большую неопределенность и шаткость» в переводе [1. С. 28]. Также исследователь утверждал, что перевод «Слов» был выполнен, по всей видимости, в Болгарии. С последним утвер- 
ждением согласны все изучавшие рукопись, однако первое утверждение подвергается значительным и обоснованным сомнениям.

Уже С.М. Кульбакин пришел к заключению, что сборник «ХІІІ Слов Григория Богослова» неоднороден по составу и содержит переводы, выполненные в разное время разными переводчиками [2. С. 24-38]. Такое же мнение высказывала Е. Коцева, утверждая, что сборник носит следы постепенного комплектования, редакционной и стилистической обработки [3. С. 246].

Л.Я. Петрова, проанализировав тексты двух гомилий сборника («Слово на Пасху» и «Слово на Рождество») пришла к выводу, что текст «Слова на Рождество» восходит к деятельности Охридской переводческой школы, а текст «Слова на Пасху» представляет собой новый перевод, сделанный в Преславе [4. С. 74].

Греческий прототип сборника «XIII Слов Григория Богослова» до сих пор не обнаружен. Количество и последовательность гомилий в славянском сборнике не соответствуют ни одной известной греческой коллекции, что заставляет ученых строить различные предположения о том, каким принципом руководствовались переводчики при его составлении. Так, А.М. Бруни выдвинул предположение, что прототипом славянского сборника явилась какая-то рукопись «частичной греческой полной коллекции, расположенной по оригинальной или особо редкой аколуфии». [5. С. 46]. Другую точку зрения на возможный греческий прототип высказал А.М. Молдаван [6. С. 9], полагая, что прототипом для сборника «ХІІІ Слов Григория Богослова» является греческая коллекция из 16 Слов, уже на славянской почве дополненная пятью нелитургическими гомилиями. Ученый обратил внимание на то, что пять «нелитургических» Слов не распределены по разным местам рукописи «XIII Слов Григория Богослова», а представляют собой цельный блок, находящийся в середине рукописи. Следовательно, рукопись ХІ в., вероятно, является копией конволюта, составленного на славянской почве. Одна из частей этого конволюта - блок из 8 гомилий, принадлежавших сборнику «XVI Слов Григория Богослова»; другая - блок из пяти гомилий, к этому сборнику не принадлежавших.

Таким образом, в истории формирования первого славянского сборника произведений Григория Богослова пока существует больше вопросов, поставленных исследователями, чем ответов.

Отличия объема и состава славянского сборника от состава греческих коллекций, как представляется, могут объясняться теми задачами, которые ставили перед собой создатели «ХІІІ Слов Григория Богослова», а именно предназначая этот сборник гомилий для недавно принявших христианство славян и используя его для миссионерских целей.

Это предположение может быть подтверждено с помощью анализа тех разночтений, которые демонстрируют славянский и греческий текст гомилий. Например, в Слове 15 находятся вставки, сделанные в расчете на славянскую аудиторию и посвященные обличению славянских языческих верований. (Их изучению посвящена работа Г.Е. Баранковой [7. С. 20-36].) В этой же гомилии есть и вставки, отражающие реалии быта славян того времени. Например, при переводе фразы греческого текста о грешниках, поклоняющихся золоту и серебру, к «змат४ и сьревр४४ добавлены «рнзннцы и овьдо»: «кма- 


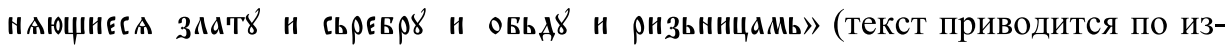
данию А.С. Будиловича [8. С. 244]). («จььдо», согласно словарю И. И. Срезневского, - «сокровище, богатство, одежда», «рнзннца» - «сокровищница») [9. C. 576, 122].

Но не только появление вставок, но также и появление некоторых лакун в гомилиях сборника «XIII Слов Григория Богослова» может быть объяснено тем, что сборник был создан с миссионерскими целями и предназначен для новообращенной славянской аудитории. Например, отрывок текста «Слова на Пасху», в котором св. Григорий Богослов объясняет происхождение слова «Пасха», в славянском переводе выпущен. Это могло быть сознательным решением переводчика, опустившего этот отрывок, поскольку для его понимания необходимо знакомство читателя с греческим языком.

О существовании лакун в сборнике «ХІІІ Слов Григория Богослова» упоминает А.М. Бруни, полагая, что «данное явление нужно в основном отнести к невнимательной работе копиистов» [5. С. 77]. С этим утверждением едва ли можно согласиться.

При внимательном рассмотрении лакун перед нами открывается достаточно сложная и интересная картина. Лакуны сборника можно разделить на группы, в одной из которых будут те пропуски, которые можно объяснить небрежностью переписчика, а в другой - те, которые кажутся вполне рациональным решением переводчика либо редактора.

Итак, рассмотрим сначала значительные по объему пропуски текста. Это следующие большие лакуны:

\section{Большие по размеру лакуны}

1) Случайные пропуски

1) Слово 6 «О мире, говоренное в присутствии отца после предшествовавшего молчания"»

Нет последних строк слова. Последняя фраза оборвана.

2) Слово 5 «Втрое обличительное на царя Юлиана»

Нет последних глав, повествование оборвано посредине предложения.

3) Слово 27 «Против евномиан и о богословии первое или предварительное»

Пропущен текст, равный по объему одному листу рукописи, последняя фраза оборвана.

\section{2) Осознанные пропуски}

1) Слово 15, «говоренное в присутствии отца, который безмолвствовал от скорби после того, как град опустошил поля»

Систематически опущены все места, где упоминается отец св. Григория Богослова, в том числе в заглавии гомилии.

\section{2) Слово 28 «О богословии второе»}

Опущены рассуждения о Боге и Божественной природе. (Есть только первая часть гомилии, где говорится о том, какими качествами нужно обладать, чтобы размышлять о Боге) 
Перед всеми лакунами, находящимися в первой колонке таблицы, текст обрывается «на полуслове», пропуск нарушает понимание смысла произведения и не может быть объяснен осознанным решением переводчика либо редактора. Лакуны же, помещенные во второй колонке, не мешают общему пониманию текста, исключая из него лишь некоторые семантически законченные фрагменты.

\section{Лакуны небольшого размера}

Эти лакуны сборника можно разделить на три группы, в первой - те пропуски, которые можно объяснить невнимательностью переписчика, во второй - те лакуны, появление которых могло быть в равной степени случайным либо намеренным, и в третьей - те, которые кажутся обусловленными рациональным решением переводчика либо редактора.

Все эти случаи представлены ниже в таблице (после греческого текста, пропущенного в переводе на славянский язык, дан перевод этого фрагмента на русский язык с расширенным контекстом; пропущенный текст обозначен курсивом).

\begin{tabular}{|c|c|c|}
\hline Случайные пропуски & $\begin{array}{l}\text { Пропуски, которые } \\
\text { могут быть как слу- } \\
\text { чайными, так и } \\
\text { осознанными }\end{array}$ & Осознанные пропуски \\
\hline 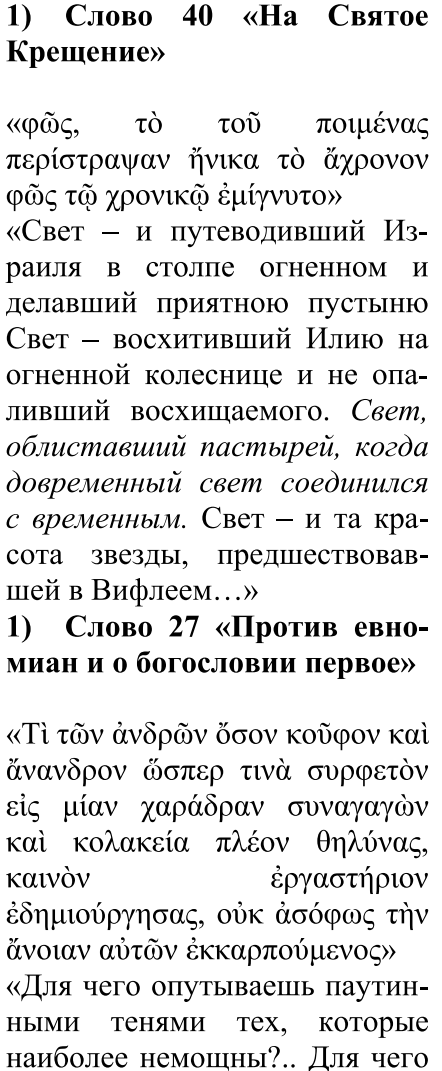 & 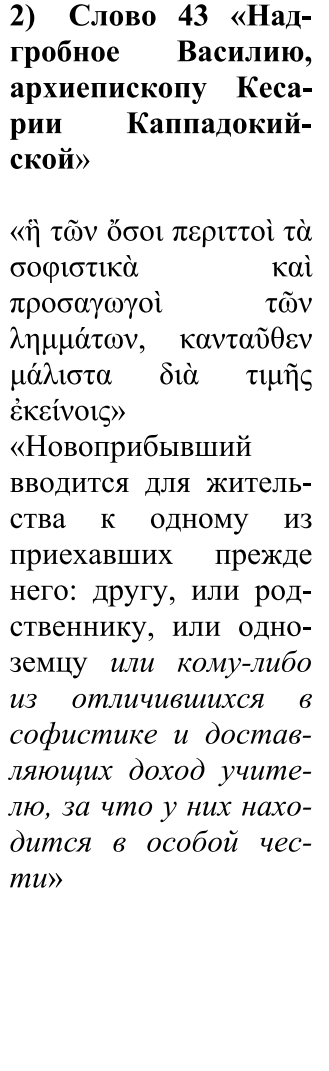 & 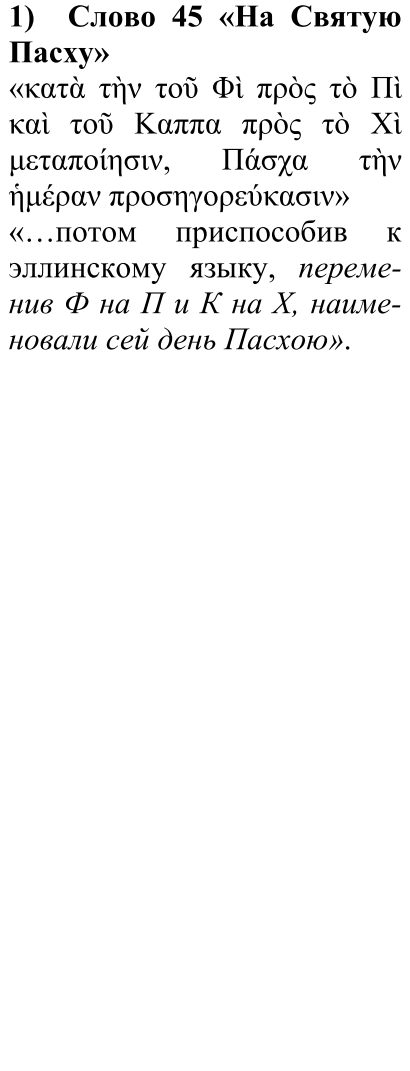 \\
\hline
\end{tabular}


\begin{tabular}{|l|l|l|}
\hline против веры возбуждаешь & \\
шершней Для чего располага- & & \\
ешь против нас состязателей?.. & \\
Для чего сколько есть между & \\
мужами легкомысленных и & \\
недостойных имени мужа, \\
собрав всех, как сор в одну яму, \\
и своим ласкательством сде- \\
лав их еще женоподобнее, по- \\
строил ть у себя новую рабо- \\
чую, и не без разума извлека- \\
ешь для себя пользу из ихъ не- \\
разумия?»
\end{tabular}

В 40-м и 27-м Словах лакуны возникли в результате пропуска в ряду риторических перечислений, начинающихся с одного и того же слова. Повидимому, эти пропуски были сделаны по невнимательности.

Пропуски текста, не вошедшие в вышеприведенные таблицы, являются незначительными по размеру и не превышают 4-5 слов. Они не были предметом рассмотрения данной статьи, однако их изучение в дальнейшим представляется достаточно перспективным для определения свободы отношения переводчиков (редакторов) к оригинальному тексту.

Итак, мы видим, что перевод гомилий, вошедших в сборник «ХІІІ Слов Григория Богослова», является не только переводом, а частично и переработкой греческого оригинала, что, вероятно, было вызвано намерением сделать текст более доступным для славянского читателя или слушателя.

\section{Литература}

1. Будилович А.С. Исследование языка древнеславянского перевода «ХІІІ Слов Григория Богослова» по рукописи Императорской Публичной библиотеки ХІ в. СПб., 1871.

2. Кульбакин С.М. Лексика старословенских превода хомилија // Глас Српске Кральевске Академије. Вып. II, 92. Београд, 1940.

3. Кочева E. Най-ранният кирилски препис от слова на Григорий Богослов // Българско средновековие: Българо-съветски сб. в чест на 70-годишнината на проф. И. Дуйчев. София, 1980. C. $240-252$.

4. Петрова Л.Я. К вопросу о древнеславянском переводе «Слов» Григория Богослова // Славяноведение. 1991. № 4. С. 70-75.

5. Бруни A.M. Теологос: Древнеславянские кодексы Слов Григория Назианзина и их византийские прототипы. // Россия и Христианский Восток. Библиотека. Вып. 6. СПб., 2004.

6. Молдаван А.М. О составе сборника 13 Слов Григория Богослова // Лингвистическое источниковедение и история русского языка (2012-2013). М., 2013. С. 5-16.

7. Баранкова Г.Е. Антиязыческие мотивы в Словах Григория Богослова (на материале древнерусских памятников письменности) // Переводные памятники философской мысли в Древней Руси. М., 1992. С. 20-36.

8. Будилович А.С. ХІІІ Слов Григория Богослова в древнеславянском переводе по рук. ПБ XI в. СПб., 1875.

9. Срезневский И.И. Материалы для словаря древнерусского языка по письменным памятникам: в 3 т. СПб., 1893-1912. 


\section{GAPS IN THE OLDEST SLAVIC TRANSLATION OF THE HOMILIES OF ST. GREGORY} OF NAZIANZUS

Vestnik Tomskogo gosudarstvennogo universiteta. Filologiya - Tomsk State University Journal of Philology. 2016. 5 (43). 24-30. DOI: 10.17223/19986645/43/2

Lyudmila V. Dolgushina, Novosibirsk State University (Novosibirsk, Russian Federation). E-mail: 1.v.dolgushina@mail.ru

Keywords: collection, gaps, Gregory of Nazianzus, translation, Slavonic language, Greek language.

The National Library of Russia in St. Petersburg stores a manuscript of the 11th century which contains the earliest translation of the homilies of St. Gregory of Nazianzus in the Slavic language. This collection is named XIII Slov Grigoriya Bogoslova [Thirteen Homilies of St. Gregory of Nazianzus].

This collection is unique not only for its antiquity (the other Slavic manuscripts with the works of St. Gregory of Nazianzus belong to the 14th century and later), but also because of the composition of the homilies. The Greek prototype of the collection is not found. The composition of the homilies as in the collection is found neither in the Greek tradition, nor in the later Slavic one.

The differences in the volume and composition of the Slavic collection from the Greek collections can be explained if to consider the aims of the compilers of this collection. We need to keep in mind that the Slavic collection was intended for the Slavs newly converted to Christianity, and it could be used for missionary purposes.

This assumption can be confirmed when considering the discrepancies between the Slavic and the Greek texts of the homilies. For example, Homily 15 has insertions devoted to denouncing Slavic pagan beliefs.

Not only the insertions, but also some gaps in the homilies of the collection could be explained by the fact that the collection was intended for the Slavs newly converted to Christianity. For example, the Slavic translation lacks an excerpt of the text of "Oration on Easter" in which St. Gregory of Nazianzus explains the origin of the word "Easter". It could be a decision of the translator to omit this passage because its understanding requires knowing some of the Greek language.

All the gaps of the collection can be divided into groups, one of which is omissions that can be attributed to the negligence and carelessness of the copyist or to the text damage, and the other one seem to be quite rational decisions of the translator or the editor.

So, the translation of the homilies included in the collection Thirteen Homilies of St. Gregory of Nazianzus is not only a translation but partly a processing of the Greek text to make it more understandable for the Slavic audience. The consideration of all the gaps of the Slavic text can probably shed light on some questions of the compilation of the collection that are still unresolved.

\section{References}

1. Budilovich, A.S. (1871) Issledovanie yazyka drevneslavyanskogo perevoda "XIII Slov Grigoriya Bogoslova" po rukopisi Imperatorskoy Publichnoy Biblioteki XI v. [Study of the Old Slavonic language translation of Thirteen Homilies of Gregory of Nazianzus, the manuscript of the Imperial Public Library in the 11th c.]. St. Petersburg.

2. Kul'bakin, S.M. (1940) Leksika staroslovenskikh prevoda khomilija [Lexicon of the Slavic translation of the homily]. In: Glas Srpske Kral'evske Akademije. II:92.

3. Kotseva, E. (1980) Nay-ranniyat kirilski prepis ot slova na Grigoriy Bogoslov [The earliest Cyrillic copy of the Homilies of Gregory of Nazianzus]. In: B"lgarsko srednovekovie: B"lgaros"vetski sb. v chest na 70-godishninata na prof. I. Duychev [Bulgarian Middle Ages: Bulgarian-Soviet collection in honor of the 70th anniversary of Prof. I. Duychev]. Sofia.

4. Petrova, L.Ya. (1991) K voprosu o drevneslavyanskom perevode "Slov" Grigoriya Bogoslova [On the question of the Old Slavonic translation of Homilies of Gregory of Nazianzus]. Slavyanovedenie. 4. pp. 70-75.

5. Bruni, A.M. (2004) Teologos. Drevneslavyanskie kodeksy Slov Grigoriya Nazianzina i ikh vizantiyskie prototipy. [Theologos. Old Slavic codes of Homilies of Gregory of Nazianzus and their Byzantine prototypes]. Rossiya i Khristianskiy Vostok. Biblioteka. 6.

6. Moldavan, A.M. (2013) O sostave sbornika 13 Slov Grigoriya Bogoslova [On the composition of the collection of Thirteen Homilies of Gregory of Nazianzus]. In: Lingvisticheskoe istochnikovedenie i istoriya russkogo yazyka (2012-2013) [Linguistic Chronology and History of the Russian language (2012-2013)]. Moscow: Drevlekhranilishche. 
7. Barankova, G.E. (1992) Antiyazycheskie motivy v Slovakh Grigoriya Bogoslova (na materiale drevnerusskikh pamyatnikov pis'mennosti) [Anti-pagan motives in the homilies of Gregory of Nazianzus (based on ancient written records)]. In: Lingvisticheskoe istochnikovedenie $i$ istoriya russkogo yazyka (2012-2013) [Linguistic Chronology and History of the Russian language (20122013)]. Moscow: Drevlekhranilishche.

8. Budilovich, A.S. (1875) XIII Slov Grigoriya Bogoslova v drevneslavyanskom perevode po ruk. $P B X I v$. [Thirteen Homilies of Gregory of Nazianzus in the Old Slavonic translation by PB 11thcentury manuscript]. St. Petersburg.

9. Sreznevskiy, I.I. (1893-1912) Materialy dlya slovarya drevnerusskogo yazyka po pis'mennym pamyatnikam. V 3-kh t. [Materials for the dictionary of ancient language based on written monuments. In 3 vols]. St. Petersburg. 